\title{
AUTONOMIA DA PROVA TÉCNICA NO PROCESSO
}

\author{
Daniel Navarro Puerari, Marco Antônio de Araujo Portes, Rodrigo Grazinoli Garrido \\ UCP. Mestrado em Direito. E-mail: grazinoli.garrido@gmail.com
}

\section{RESUMO}

A prova técnica é obtida pela analise científica de evidências materiais relacionadas a um litígio, auxiliando o julgador. Esta goza de grande influência na sociedade atual, apesar de processualmente se mostrar hierarquicamente nivelada aos outros meios de prova. Como a legislação resguarda ao juiz livre apreciação das provas para seu convencimento, este pode desconsiderar a necessidade do exame pericial ou os resultados do mesmo. Dessa forma, buscouse avaliar o grau de autonomia que goza a prova técnica no processo, avaliando as limitações do juízo na sua apreciação. Foi possível concluir que o controle total do juiz sobre a produção e valoração da prova técnica é contrário à visão do processo democrático. No entanto, para que não reste dúvida quanto ao valor da prova técnica, esta deve respeitar métodos científicos modernos e normatizados, que obedeça a um sistema de gestão da qualidade e que respeite ao máximo o contraditório.

Palavras-chave: processo civil; processo penal; prova científica; ciência forense; perícia

\section{AUTONOMY OF THE TECHNICAL EVIDENCE IN THE PROCEDURE}

\begin{abstract}
The technical evidence is obtained by analysis of scientific material evidence related to a dispute, assisting the judge. This enjoys great influence in current society, although procedurally show the same hierarchical level to other evidence. As legislation protects the free assessing of the judge to the evidence for his conviction, this can disregard the need for forensic examination or the results thereof. Thus, we sought to assess the degree of autonomy enjoyed by the technical evidence in the procedure, evaluating the limitations of judgment in its assessment. It was concluded that the total control of the judge on the production and assessment of technical evidence is contrary to the vision of the democratic process. However, for the avoidance of doubt about the value of technical evidence, it must comply with modern and standardized scientific methods, which observes a quality management system, and respects the most adversarial.
\end{abstract}

Keywords: civil procedure; criminal procedure; scientific evidence; forensic science; forensics 


\section{INTRODUÇÃO}

Entre os meios possíveis de prova existentes, a prova pericial é aquele em que se lança mão de conhecimentos técnico-científicos para reconhecer e interpretar evidências materiais relacionadas a um fato que ensejou um litígio. Apesar de não apresentar posição hierárquica superior aos outros meios de prova na avaliação judicial, a prova técnica goza de grande influência na sociedade atual, pois carrega a credibilidade do que é científico.

Apesar de se ter pretensões diferentes no processo civil e penal no que se relaciona à verdade dos fatos, em ambos os procedimentos a prova técnica é demandada para auxiliar o julgador. Todavia, no processo penal, a prova técnica é produzida pelo Estado como um dever, sempre que a infração deixar vestígios.

Apesar do exposto, a legislação permite que o juiz aprecie as provas de forma livre, a fim de gerar sua convicção. Assim, de forma monocrática, o julgador pode desconsiderar a necessidade do exame pericial ou os resultados do laudo pericial.

Dessa forma, por meio de pesquisa exploratória e descritiva, desenvolvida a partir de documentação indireta de fontes primárias e secundárias, buscou-se reconhecer o grau de autonomia que goza a prova técnica nos processos civil e penal, avaliando as limitações impostas pelo juízo na sua apreciação.

\section{A PROVA TÉCNICA}

Humberto Theodoro Jr. (2012) define prova técnica, ou pericial, como sendo "o meio de suprir a carência de conhecimentos técnicos de que se ressente o juiz para apuração dos fatos litigiosos". Em continuidade, a perícia seria a diligência realizada por pessoa física, o perito, no intuito de analisar tecnicamente um fato e instruir o procedimento legal (FILHO, 2011). Contudo, o processo pode também abrigar provas oriundas de interrogatórios, confissões, testemunhas e documentos.

Assim, a prova pericial é essencialmente técnico-científica e produzida por uma diversidade de conhecimentos requeridos de acordo com o objetivo do exame e da natureza do fato e das evidências deixadas após este. Todavia, pode-se definir que a prova pericial é produzida no âmbito da Ciência Forense, pois segundo Gialamas (2000), tal ciência é originada da aplicação do saber científico humano à matéria ou aos problemas do Direito nos seus diversos ramos.

Tendo em vista que a ciência goza de extrema influência na sociedade atual, adotar cientificidade a algo é forma de emprestar a isto plena credibilidade associada à ciência (FACHONE e VELHO, 2007), apesar do conhecimento obtido pelo método científico ser, sobretudo, limitado e 
reducionista. Com isso, tem-se buscado cada vez mais provas "indiscutíveis" fundadas na evolução científica (CALLEGARI, WERMUTH e ENGELMANN, 2012).

\section{O PAPEL DA PROVA TÉCNICA NO PROCESSO}

Na cultura jurídica nacional, estabeleceram-se princípios de "verdade" diferentes entre o processo civil e penal. No processo civil, seria suficiente uma verdade formal (PEREIRA, 2010). Isto é, tendo em vista um bem jurídico na maioria das vezes disponível, bastaria uma verdade realtiva, trazida ao processo pelas partes, para que se alcançassem por negociação a resolução da contenda e a suficiente "felicidade" dos envolvidos. Não obstante, o valor da prova pericial é reconhecido de acordo com o artigo 145, do Código de Processo Civil Quando a prova do fato depender de conhecimento técnico ou científico, o juiz será assistido por perito,segundo disposto no Art. 421 (BRASIL, 1973).

Do ponto de vista processual penal, quando o bem jurídico em questão é indisponível, como a liberdade, tornar-se-ia necessária uma verdade real (PEREIRA, 2010). Quanto a esta, as possibilidades das partes transacionarem são limitadas. Assim, para alcançá-la, o julgador deveria realizar todos os esforços de forma a produzir as provas necessárias para esclarecimento dos fatos, inclusive, fazendo uso de seus poderes inquisitoriais para determinar ex officio diligências necessárias (GRECO FILHO, 2013; MIRABETE e FABRINI, 2014).

Nesse sentido, o legislador processual penal decidiu no Art. 158 que Quando a infração deixar vestígios será indispensável o exame de corpo de delito, direto ou indireto, não podendo supri-lo a confissão do acusado. (BRASIL, 1941). Assim, não se trata de uma faculdade do Estado, mas um dever de realizar a perícia. Além disso, a obrigação do Estado na produção da prova técnica inicia-se antes mesmo da instauração do inquérito policial, pois a autoridade policial, ao ter conhecimento da prática da infração penal, deverá (Art 6으, VII) determinar, se for caso, que se proceda a exame de corpo de delito e a quaisquer outras perícias. Além disso deve providenciar para que não se altere o estado das coisas até a chegada dos peritos (Art.169, CPP).

\section{AUTONOMIA DO JUIZ NA APRECIAÇÃO DA PROVA TÉCNICA}

Tanto no processo civil (Art 131), quanto no penal (Art. 155), fica clara a inexistência de hierarquia entre os tipos de prova. Dessa forma, o juiz gera sua convicção pela livre apreciação das provas, racionalmente balizado.

A clara concentração decisória que o legislador atribuiu ao juiz, não causa estranheza, visto ser esta a real função do juiz. Contudo, a crítica reside justamente quando estamos diante de um 
fato comprovado pela prova pericial. Uma vez que o magistrado se socorreu dos trabalhos técnicos, específicos e indispensáveis, para poder conhecer de assuntos que não lhe são afetos, como poderia, ao final da demanda, julgar em desconformidade com as conclusões apostadas no laudo pericial e contestadas/trabalhadas pelos assistentes técnicos? De onde surgiu a repentina habilidade técnica do magistrado?

Entretanto, tal modelo pode ser criticado, encontrando a doutrina contemporânea a adequada solução, que seria a obtenção de uma efetiva comparticipação processual, migrando do sistema pautado no denominado "solipsismo judicial", no qual o juiz denominado "juiz narcisista" toma para si o controle absoluto do processo, para o "policentrismo processual", modelo no qual não mais o magistrado estaria no centro do processo. Apesar de figura fundamental à entrega da prestação jurisdicional, o juiz prestaria a jurisdição numa atuação equilibrada com as partes processuais e demais auxiliares da justiça, como o perito (NUNES, 2008).

Ademais, apesar dos esforços da doutrina para rever o problema acima exposto, o legislador brasileiro mantém a mesma postura. O anteprojeto do código de processo civil, que em breve se transformará no denominado novo CPC (PL 8046/2010) não mudou em nada o presente dilema, como se vê:

"Art. 459. O juiz não está adstrito ao laudo pericial, podendo formar a sua convicção com outros elementos ou fatos provados nos autos"

A seu turno, no processo penal, há obrigação do Estado em produzir a prova pericial nos crimes que deixam vestígios. Nestes, a análise das modificações materiais deixadas pela infração (exame de corpo de delito) é indispensável, sob pena de nulidade da prova e absolvição do acusado, o que parece reduzir significativamente a liberdade de apreciação pelo juiz (BRASIL, 1941).

Contudo, além do juiz não ficar adstrito ao laudo pericial para julgar, a própria demanda de exame pericial tem-se tornado relativa. Na visão do Ministro Gilmar Mendes em julgado do Supremo Tribunal Federal, a alegação de nulidade do processo pela falta do exame de corpo de delito é improcedente na existência de outros elementos de prova (BRASIL, 2005).

Além disso, há quem questione a aparente supremacia da prova pericial, uma vez que esta pode cercear a defesa, pois o exame de corpo de delito é, na maioria das vezes, produzido de forma cautelar, irrepetível, no inquérito policial sem a participação das partes (BASTOS e ORÇAI, 2007). Estes autores chegam a dizer que:

Há de se dar preferência às outras provas, tornando-se o exame de corpo de delito prescindível, sobretudo diante de provas colhidas sob o crivo do 
contraditório, tomado em todas as suas atuais dimensões (BASTOS e ORÇAl, 2007).

Contudo, com a Lei $11.690 / 2008$, instituiu-se o assistente técnico indicado pelas partes no processo penal. Assim, para aqueles exames que puderem ser repetidos ou que ainda estiverem em processamento na fase acusatória da ação penal o contraditório e garantido (BRASIL, 2008).

Para tanto, há que se estimular a normatização de exames e os órgãos periciais devem assegurar a cadeia de custódia idônea e rastreável dos materiais apreendidos para além dos exames, mas enquanto for de interesse para a justiça (SABINO et al., 2012). Para tanto, devem envidar esforços para a implantação de um Sistema de Gestão da Qualidade (SGQ) para a área forense (GARRIDO e ARAUJO, 2014).

\section{CONCLUSÃO}

O processo deve ser visto como uma forma de acessar a justiça e não o contrário. $\mathrm{O}$ controle total do juiz sobre a produção e valoração da prova pode afrontar à segurança jurídica, fundamental à prestação jurisdicional justa. Todavia, um sistema jurisdicional democrático está longe de se tornar realidade, esforçando-se para romper com longo período de autocracia imortalizada com o dizer latino luri novit curia e no brocardo da mihi factum, dabo tibi ius (DÉRLEN, 2009). Tal fase se fez necessária em determinado momento da sociedade, mas, atualmente não encontra mais espaço.

Não se deseja a total e cega aceitação da prova técnica em detrimento de outros meios de prova que possam contribuir na geração da convicção do julgador, mas a valorização da prova realizada dentro dos métodos científicos mais modernos, normatizados, obedecendo a um sistema de gestão da qualidade e que na elaboração esforce-se para garantir o contraditório, por meio da resposta a quesitos elaborados ou pela atuação do assistente técnico contratado pela parte ré.

\section{REFERÊNCIAS}

BRASIL, Decreto-Lei no 3.689, de 3 de outubro de 1941. Código de Processo Penal, 1941.

BRASIL, Lei no 5.869, de 11 de janeiro de 1973. Institui o Código de Processo Civil, 1973.

BRASIL. Senado Federal. Projeto de Lei no 8046/2010. Revoga a Lei no 5.869, de 1973.

BRASIL. Lei no 11.690. Altera dispositivos do Decreto-Lei no 3.689, de 3 de outubro de 1941 Código de Processo Penal, relativos à prova, e dá outras providências, 2008. 
BRASIL, Supremo Tribunal Federal, habeas corpus no 85.744-2/RJ, 2a. Turma, Relator: Ministro Gilmar Mendes, julgamento em 02/08/2005. Disponível em: www.stf.gov.br. Acessado em 10 ago 2014.

CALLEGARI, A.L.; WERMUTH, M.A.D. e ENGELMANN, W. DNA e Investigação Criminal no Brasil. Ed. Livraria do Advogado, 2012, 100p.

DERLÉN, M. Kluwer Law International, ed. Multilingual interpretation of European Union law. European monographs 67. 2009, p. 314.

FACHONE, P. e VELHO, L. Ciência Forense: Interseção Justiça, Ciência e Tecnologia. Revista Tecnologia e Sociedade, no 4, p. 139-161, 2007.

FILHO, R.P.A. Da Perícia ao Perito. Editora Impetus. 3ạ ed., 2011.

GARRIDO, R.G. e GIOVANELLI, A. Ciência Forense. Uma Introdução à Criminalística. FAPERJ, 2012, $182 \mathrm{p}$.

GARRIDO, R.G. e ARAUJO, K. Sistemas de Gestão da Qualidade em Laboratório de Genética Forense. Revista Espacios. V35(5), p.3-8, 2014.

GIALAMAS D.M. Criminalistics. In: Siegel J, Knupfer G, Saukko P, editors. Encyclopedia of forensic sciences. Elsevier; 2000. p. 471-47.

GRECO FILHO, V. Manual do Processo Penal, 10a Ed. Ed. Saraiva, 2013.

BASTOS, M.L. e ORÇAI, M.C.. Exame de corpo de delito - o art. 158 do código de processo penal e uma releitura à luz do princípio do contraditório e das novas regras do interrogatório (lei no 10.792/03). In: XVI Congresso do CONPEDI, Belo Horizonte. Anais do XVI Conpedi, 2007. Disponível em: www.conpedi.org.br/manaus/arquivos/anais/bh/marcella cordeiro or\%E7ai.pdf. Acesso em: 10 ago 2014.

MIRABETE, J.F. e FABRINI, R.N. Manual de Direito Penal. Vol. I, II e III. Ed. Atlas, 2014.

NUNES, Dierle José Coelho. Processo jurisdicional democrático 1ạ. ed. Juruá, 2008.

PEREIRA, M.F.R. A tirania da verdade no processo penal brasileiro: às voltas com o "princípio" da verdade real. Revista Espaço Acadêmico. № 115, p.95-102, 2010.

SABINO, B.D., GIOVANELLI, A., BORGES, R., GARRIDO, R.G. De que forma a análise forense de drogas pode afetar os Direitos Humanos Fundamentais? Revista Brasileira de Ciências Criminais. v. 95, p.195 - 212, 2012.

THEODORO Jr., H.. Teoria Geral do Direito Processual Civil I. 53. ed. Rio de Janeiro: Forense, 2012. 